Олександр Антонович Сціборовський (канд. психолог. наук, доцент)

Артем Володимирович Братко (канд. військ. наук)

Національна академія Державної прикордонної служби Украӥни імені Богдана Хмельницького, Хмельницький, Украйна

\title{
МЕТОДИЧНІ РЕКОМЕНДАЦІЇ З ОРГАНІЗАЦІЇ ЗАСТОСУВАННЯ ПІДРОЗДІЛІВ СКЛАДУ БОЙОВОГО РЕЗЕРВУ ДЛЯ ПОСИЛЕННЯ ОХОРОНИ ДЕРЖАВНОГО КОРДОНУ
}

В даній статті авторами досліджено та науково обгрунтовано рекомендації, щчо визначають єдиний підхід департаментів Адміністрації Державної прикордонної служби України, штабів регіональних управлінь, прикордонних загонів, командирів підрозділів до організації застосування підрозділів складу бойового резерву Голови Державної прикордонної служби Украӥни для посилення охорони державного кордону. Визначено умови та правила залучення підрозділів складу бойового резерву для посилення охорони державного кордону, порядок організації оперативно-службової діяльності та порядок виконання завдань.

Ключові слова: бойові резерви, прикордонні підрозділи, державний кордон, мобільна група, прикордонний наряд, відділ прикордонної служби.

\section{Вступ}

Сили та засоби реагування на зміни обстановки, а також резерви призначені для виконання таких типових завдань:

цілодобовий моніторинг обстановки та реагування на ії зміни;

нарощування зусиль органів та підрозділів охорони державного кордону 3 протидії правопорушенням, які віднесені до компетенції Державної прикордонної служби України;

реалізації оперативної інформації про можливі порушення державного кордону;

локалізація конфліктних (нетипових) та надзвичайних ситуацій техногенного, природного характеру;

участі у межах компетенції прикордонної служби у боротьбі 3 тероризмом й виконанні інших раптово виникаючих завдань на державному кордоні, у пунктах пропуску через державний кордон.

Постановка проблеми. Існує ряд невирішених питань, а саме впорядкування умов та правил залучення підрозділів складу бойового резерву для посилення охорони державного кордону, порядку організації оперативно-службової діяльності та порядку виконання завдань.

Аналіз остатніх досліджень і публікацій. Нами було проведено аналіз наявних керівних документів щодо порядку організації оперативнослужбової діяльності [1-5]. Враховуючи умови та виклики сьогодення постало питання приведення до загальних правил, а саме порядку роботи щодо організації оперативно-службової діяльності підрозділів складу бойового резерву для посилення охорони державного кордону. Питаннями застосування сил та засобів в охороні державного кордону займались такі науковці як Назаренко В. О., Олексієнко Б. М., Серватюк В. М., Катеринчук І. С. Однак більшість наукових праць вказують на наявні проблеми в застосуванні сил та засобів, та не в повній мірі вирішують проблематику.

Метою статті $\epsilon$ дослідити та науково обгрунтувати рекомендації, що визначають єдиний підхід департаментів Адміністрації Державної прикордонної служби України, штабів регіональних управлінь, прикордонних загонів, командирів підрозділів до організації застосування підрозділів складу бойового резерву Голови Державної прикордонної служби України для посилення охорони державного кордону. Визначити умови та правила залучення підрозділів складу бойового резерву для посилення охорони державного кордону, порядку організації оперативно-службової діяльності та порядку виконання завдань.

\section{Виклад основного матеріалу}

\section{дослідження.}

Підрозділи складу бойового резерву можуть бути задіяні для посилення охорони державного кордону:

за рішенням Голови Державної прикордонної служби України;

за рішенням начальника регіонального управління при настанні сукупності відповідних умов.

Умови застосування підрозділів складу бойового резерву для посилення охорони державного кордону:

використання органом управління (регіонального управління, прикордонного загону) всіх ресурсів підрозділів і наявних резервів;

якщо обстановка вимагає залучення для посилення охорони кордону додаткових сил i засобів;

після затвердження Голови Державної прикордонної служби України замислу начальника 
регіонального управління на посилення охорони державного кордону із застосуванням резервів.

Для виконання завдань 3 посилення охорони державного кордону можуть застосовуватись лише штатні прикордонні підрозділи (прикордонна застава, відділення інспекторів прикордонної служби, відділення прикордонного контролю) прикордонних комендатур швидкого реагування та оперативно-бойових прикордонних комендатур (далі - комендатури).

За потреби, залежно від обстановки на ділянці, яка потребує посилення, виділені для охорони державного кордону підрозділи можуть посилюватись розрахунками групової зброї, технікою (броньованою або спеціальною), матеріально-технічними засобами бойових підрозділів і підрозділів забезпечення комендатур.

Як виняток для посилення охорони державного кордону самостійно можуть застосовуватись оперативні зенітно-артилерійські та протитанкові прикордонні застави прикордонних загонів, бойові підрозділи та підрозділи забезпечення комендатур.

Для виконання окремих особливо важливих (спеціальних) завдань на ділянці відповідальності прикордонного загону в якості мобільної групи може застосовуватись відділення розвідки комендатури.

Підрозділи складу бойового резерву застосовуються для посилення охорони окремих найбільш активних напрямків протиправної діяльності шляхом визначення прикордонним заставам (відділенням інспекторів прикордонної служби) ділянок державного кордону або районів застосування в межах ділянки відповідальності одного чи двох суміжних відділів прикордонної служби, на яких необхідно здійснити нарощування сил i засобів, окремих завдань i способів їх виконання.

Призначений для посилення охорони державного кордону підрозділ складу бойового резерву направляється на визначену ділянку на своїй штатній техніці, зі штатним озброєнням, під керівництвом штатного начальника (командира), де представником (оперативною групою) органу, від якого він направляється, передається в оперативне підпорядкування начальнику прикордонного загону, на ділянці якого планується застосування (з виданням відповідного наказу прикордонного загону та оформленням актів приймання/передачі).

3 метою організації зустрічі підрозділів на ділянці, передачі та прийняття їх в оперативне підпорядкування, доведення завдань, проведення рекогносцировки та організації взаємодії i контролю за оперативно-службовою діяльністю від органів управління призначаються оперативні групи.

Підрозділу складу бойового резерву, призначеному для посилення охорони державного кордону, визначаються:

пункт призначення i місце (район) розташування на місцевості; порядок висунення 3 пункту постійної дислокації (ППД) до пункту призначення;

ділянка державного кордону або район застосування для посилення охорони державного кордону;

оперативно-службові завдання та порядок їх виконання;

метод облаштування місця (району) розташування (опорний пункт, наметове містечко, окремі будівлі) та порядок його охорони і оборони.

На ділянках кордону з Російською Федерацією, Республікою Білорусь, центральній ділянці кордону 3 Республікою Молдова, на адміністративній межі 3 тимчасово окупованою територією АР Крим та в районі АТО - в обов'язковому порядку розташування підрозділу визначається в опорному пункті 3 вогневими позиціями для засобів ураження, бойової техніки, укриттями для особового складу і техніки.

Вибір місця облаштування опорного пункту здійснюється штабом прикордонного загону 3 урахуванням можливості подальшого його використання в загальній системі участі Державної прикордонної служби України (ДПСУ) в територіальній обороні та у відсічі збройній агресіi.

Ділянка (район) застосування підрозділу визначаються $з$ урахуванням:

тактики дій правопорушників;

часу, необхідного для гарантованого їх перехоплення на вигідних позиціях;

особливостей місцевості;

розміщення інженерних споруд і загороджень.

У разі прийняття підрозділом складу бойового резерву під охорону окремої ділянки державного кордону наказом начальника регіонального управління визначаються стики, розмежувальні лінії з ділянками підрозділів охорони кордону та глибина ділянки підрозділу.

Глибина ділянки підрозділу встановлюється умовною лінією, що поєднує останні точки, які визначають розмежувальні лінії ії ділянки.

У випадку, якщо посилення охорони державного кордону підрозділом складу бойового резерву полягає в організації виконання окремих завдань (рейдові, патрульні та інші спеціальні дії) iз залученням невеликого за чисельністю особового складу підрозділу (відділення розвідки, мобільна група), його розташування може бути організовано на території або у приміщеннях прикордонного містечка відділу прикордонної служби.

Підрозділ бойового резерву в ході посилення охорони державного кордону взаємодіє 3 відділом (відділами) прикордонної служби, районних оперативно-розшукових відділів, на ділянці відповідальності (обслуговування) яких здійснюється посилення охорони державного кордону.

Під час виконання завдань 3 підрозділами проводяться заходи злагодженості дій за призначенням (тренування вогневих розрахунків, екіпажів, секцій). 
Всебічне забезпечення підрозділу складу бойового резерву здійснюється:

на час висунення підрозділу з ППД до пункту призначення - за рахунок органу ДПСУ, в штаті якого він знаходиться;

під час посилення ним охорони державного кордону та повернення в ППД - за рахунок прикордонного загону, на ділянці якого виконуються завдання.

Організація застосування підрозділів складу бойового резерву для посилення охорони державного кордону здійснюється на підставі наказів, методичних рекомендацій про порядок організації застосування прикордонної комендатури швидкого реагування, практичних рекомендацій та інших керівних документів Адміністрації ДПСУ.

Рішення про застосування підрозділів складу бойового резерву начальник регіонального управління приймає на підставі висновків 3 оцінки обстановки.

Замисел начальника регіонального управління на посилення охорони державного кордону із застуванням підрозділів складу бойового резерву направляється в Адміністрацію ДПСУ для затвердження Головою Державної прикордонної служби України.

У рішенні визначаються:

замисел дій;

завдання підрозділам складу бойового резерву та підрозділам охорони державного кордону, на ділянці яких плануються дії;

основні питання взаємодії, управління і всебічного забезпечення.

У замислі визначаються:

напрямки зосередження основних зусиль органів охорони державного кордону, на які планується застосування бойових резервів;

склад підрозділу бойового резерву, якими засобами посилений та старші;

ділянка (район) застосування;

район (місце) і порядок розташування (опорний пункт, наметове містечко);

способи та порядок виконання завдань підрозділами складу бойового резерву, включаючи порядок їх переміщення.

В основних питаннях взаємодії визначається порядок взаємодії підрозділів складу бойового резерву, підрозділів охорони державного кордону, 3СУ, інших військових формувань та правоохоронних органів під час виконання поставлених завдань по рубежах, напрямках дій і часу.

У питаннях управління визначається порядок управління підрозділами під час дій, завдання i порядок роботи органів управління, заходи забезпечення стійкості та безперервності управління.

Оперативно-службова діяльність підрозділу складу бойового резерву в ході посилення охорони визначеної ділянки державного кордону здійснюється на підставі наказів (розпоряджень) начальника регіонального управління, начальника прикордонного загону, на ділянці якого застосовується підрозділ та начальника органу управління, від якого підрозділ направляється для посилення.

Наказ регіонального управління про посилення охорони державного кордону із застосуванням резервів опрацьовується штабом регіонального управління на підставі рішення начальника регіонального управління після затвердження Головою ДПСУ відповідного замислу або після отримання окремого розпорядження Адміністрації ДПСУ.

Вимоги наказу доводяться до прикордонних загонів (органу ДПСУ) розпорядженнями.

Наказ прикордонного загону, на ділянці якого планується посилення охорони кордону, опрацьовується штабом загону на підставі розпорядження регіонального управління та окремими розпорядженнями доводиться до підрозділів охорони кордону і підрозділу складу бойового резерву, який прибуває для посилення.

Наказ прикордонного загону (органу ДПСУ), від якого призначається підрозділ для посилення охорони кордону, опрацьовується штабом загону (органу ДПСУ) на підставі розпорядження регіонального управління та окремим розпорядженням доводиться до підрозділу складу бойового резерву (прикордонна комендатура швидкого реагування (приккшр), окрема бойова прикордонна комендатура (обпк), окрема зенітноартилерійська прикордонна застава (озаприкзас), окрема протитанкова прикордонна застава (оптприкзас)).

У наказі (розпорядженні) регіонального управління 3 посилення охорони державного кордону прикордонним загонам вказуються:

напрямки, ділянки посилення державного кордону (райони застосування), які необхідно посилити підрозділом (підрозділами) складу бойового резерву;

категорія підрозділів посилення (застава, відділення інспекторів прикордонної служби) та їх кількісний склад, терміни виконання ними завдань;

межі районів застосування, а у разі визначення ділянок відповідальності - стики та розмежувальні лінії з підрозділами охорони державного кордону;

необхідне для виконання завдань озброєння та технічні засоби охорони державного кордону (ТЗОДК);

порядок і термін здійснення маршу підрозділів, пункти зустрічі та місця (райони) розташування на місцевості;

порядок i терміни проведення прийому/передачі підрозділів в оперативне підпорядкування, визначення їм завдань на здійснення оперативно-службової діяльності (ОСД);

порядок організації взаємодії з підрозділами ДПСУ, Збройних Сил, Національної гвардії України в разі їх знаходження на ділянці (в районі) застосування; 
порядок організації та здійснення всебічного забезпечення ОСД підрозділів посилення;

загальний порядок організації системи управління та подання донесень;

термін готовності до виконання завдань.

У наказі (розпорядженні) прикордонного загону з посилення охорони державного кордону підрозділам вказуються:

напрямки та ділянки державного кордону, які необхідно посилити;

який підрозділ, коли і на який термін прибуде для посилення, визначені перед ним завдання;

склад оперативної групи для прийняття підрозділу посилення в оперативне підпорядкування та організації його оперативнослужбової діяльності;

порядок організації зустрічі підрозділу посилення, прийняття його в оперативне підпорядкування, розташування у визначеному місці (районі) та його облаштування;

порядок проведення рекогносцировки ділянки (району) та передачі/прийняття іiі (його) під охорону;

порядок організації та здійснення оперативнослужбової діяльності прийнятим в оперативне підпорядкування підрозділом посилення;

напрямки (завдання на) зосередження основних зусиль в межах ділянки (в межах району) та порядок їх охорони, організація служби на решті ділянки (району);

порядок озброєння прикордонних нарядів;

питання взаємодії з відділами прикордонної служби, районними оперативно-розшуковими відділами, підрозділами Збройних Сил, Національної гвардії України в разі їх знаходження на ділянці (в районі) застосування, а також сигнали оповіщення і порядок дій у разі різкої зміни обстановки;

порядок здійснення всебічного забезпечення ОСД;

порядок організації управління та зв'язку, інформування про обстановку;

термін готовності до виконання завдань.

У наказі (розпорядженні) органу охорони державного кордону, від якого направляється підрозділ посилення, вказуються:

загальні завдання та терміни їх виконання;

підрозділ посилення (застава, відділення інспекторів прикордонної служби), його кількісний склад і старший, техніка, озброєння та необхідні ТЗОДК;

сили i засоби посилення від підрозділів бойового (всебічного) забезпечення;

необхідність забезпечення

матеріально-технічними засобами;

склад оперативної групи для супроводу i здійснення передачі підрозділу посилення в оперативне підпорядкування іншому органу управління;

порядок і термін здійснення маршу та пункт (пункти) зустрічі;

порядок i терміни здійснення передачі підрозділу в оперативне підпорядкування прикордонного загону, на ділянці якого планується застосування;

порядок організації управління підрозділом у ході підготовки та на марші;

термін готовності до висунення.

Завдання до підрозділу складу бойового резерву доводяться штабами прикордонних загонів (органу ДПСУ) окремими розпорядженнями, які надсилаються в підрозділи та записуються у відповідні розділи книг прикордонної служби:

на підготовку до дій, здійснення маршу та перехід в оперативне підпорядкування визначеному органу управління - із записом в книзі прикордонної служби (КПС) комендатури;

на виконання завдання 3 посилення охорони державного кордону - після прийняття підрозділу в оперативне підпорядкування під час безпосередньої організації ОСД із записом в КПС прикордонної застави (відділення інспекторів прикордонної служби) або в робочий зошит начальника відділення розвідки (старшого мобільної групи).

3 прибуттям підрозділу складу бойового резерву до пункту розташування обладнуються командно-спостережний пункт (КСП) підрозділу, місця для відпочинку та життєдіяльності особового складу, місця всебічного забезпечення діяльності підрозділу.

Посилення охорони державного кордону на визначеній ділянці (в районі) здійснюється шляхом організації служби окремих змін прикордонних нарядів і щодобового планування служби прикордонних нарядів 3 відпрацюванням на формалізованих бланках планів організації служби і розпорядків дня (режимів роботи) змін прикордонних нарядів на добу 3 подальшим занесенням інформації до КПС прикордонних застав (відділень інспекторів прикордонної служби) або робочих зошитів начальників відділень розвідки (старших мобільних груп), які мати на КСП підрозділів.

Робота командира підрозділу посилення під час організації та здійснення посилення охорони державного кордону на визначеній ділянці (в районі) здійснюється відповідно до методичних рекомендацій про порядок організації застосування прикордонної комендатури швидкого реагування.

Організація служби прикордонних нарядів здійснюється відповідно до вимог Інструкції про службу прикордонних нарядів Державної прикордонної служби України [3].

Під час визначення порядку виконання завдань підрозділу складу бойового резерву вказуються бойовий порядок, якими силами i засобами виконував поставлені завдання, а також дії підрозділу в разі ускладнення обстановки.

Місця організації служби окремих прикордонних нарядів (прикордонний патруль, контрольний пост, секрет тощо) визначаються виходячи з висновків з оцінки обстановки. 
Оперативно-службова діяльність підрозділу складу бойового резерву для: посилення охорони державного кордону та результати служби обліковуються:

на приккшр та обпк (озаприкзас та оптприкзас) - в КПС комендатур (застав) та місячних планах основних заходів підрозділу;

у прикордонних заставах (відділеннях інспекторів прикордонної служби) - в КПС застав (відділень інспекторів прикордонної служби);

у бойових підрозділах і підрозділах забезпечення - в робочих зошитах; командирів підрозділів.

Крім вищевказаних документів, в кожному підрозділі, призначеному для посилення охорони державного кордону, ведуться:

робочий зошит командира (начальника) підрозділу;

робоча карта командира (начальника) підрозділу;

схема охорони пункту дислокації підрозділу;

розрахунок сил і засобів підрозділу для дій за командами тривог;

журнал збору даних обстановки;

журнал отриманих та відданих розпоряджень; журнал службово-бойових дій;

формалізовані бланки планів організації служби та розпорядків дня (режимів роботи) змін прикордонних нарядів на добу.

Організація застосування підрозділів складу бойового резерву для посилення охорони державного кордону покладається:

в Адміністрації Державної прикордонної служби України - на управління прикордонної служби Департаменту охорони державного кордону;

у регіональних управліннях - на відділи прикордонної служби штабів регіональних управлінь;

у прикордонних загонах - на відділи прикордонної служби штабів прикордонних загонів.

\section{Jimepamypa}

1. Про затвердження Інструкції про порядок роботи органів управління Державної прикордонної служби України під час організації оперативнослужбової діяльності : наказ Адміністрації Держприкордонслужби України від 08.10.2010 №755. К. : АДПСУ, 2010. - С. 10-15. 2. Тимчасова інструкція про застосування мобільних підрозділів : наказ Адміністрації Держприкордонслужби України від 30.12.2005 № 1039. 3. Інструкція про службу прикордонних нарядів Державної прикордонної служби України, затвердженої наказом Міністерства внутрішніх справ України від 19.10.15 № 1261 . 4. Про
Посилення заходів у пунктах пропуску через державний кордон (КПВВ) покладаються - на управління прикордонного контролю Департаменту охорони державного кордону Адміністрації ДПСУ, відділи прикордонного контролю штабів регіональних управлінь та прикордонних загонів.

Залучення підрозділів складу бойового резерву для реалізації оперативної інформації, участі у спецопераціях 3 протидії тероризму, боротьби 3 транскордонною злочинністю, контрабандною діяльністю, припинення злочинів, службових i корупційних правопорушень - на Департамент оперативної діяльності, управління внутрішньої та власної безпеки Адміністрації ДПСУ, відповідні структурні підрозділи в регіональних управліннях.

\section{Висновки й перспективи подальших досліджень}

Таким чином, у статті авторами досліджено та науково обгрунтувати рекомендації, що визначають єдиний підхід департаментів Адміністрації Державної прикордонної служби України, штабів регіональних управлінь, прикордонних загонів, командирів підрозділів до організації застосування підрозділів складу бойового резерву Голови Державної прикордонної служби України для посилення охорони державного кордону. Визначено умови та правила залучення підрозділів складу бойового резерву для посилення охорони державного кордону, порядку організації оперативно-службової діяльності та порядку виконання завдань.

Подальші дослідження в даному напрямку забезпечать постійне вдосконалення та пошук нових методів, прийомів та способів щодо підвищення ефективного застосування сил, засобів резервів та розробку обгрунтованих алгоритмів дій елементів системи управління.

затвердження Інструкції 3 організації оперативнослужбової діяльності відділу прикордонної служби Державної прикордонної служби України : наказ Адміністрації Держприкордонслужби від 29.12.2009 № 1040. - Хмельницький : Вид-во НАДПСУ, 2010. 175 с. 5. Повноваження органів управління 3 організації застосуванні підрозділів складу бойового резерву, затверджені наказом АДПСУ від 22.12.2017 № 120. 6. Кондрат В. Ф. Проблеми ефективності використання мобільних підрозділів в охороні державного кордону / В.Ф. Кондрат, О.В. Решетніков // Науковий вісник ДПСУ. - 2004. - №4. - С. 14-16

\title{
МЕТОДИЧЕСКИЕ РЕКОМЕНДАЦИИ ПО ОРГАНИЗАЦИИ ПРИМЕНЕНИЯ ПОДРАЗДЕЛЕНИЙ ИЗ СОСТАВА БОЕВЫХ РЕЗЕРВОВ ДЛЯ УСИЛЕНИЯ ОХРАНЫ ГОСУДАРСТВЕННОЙ ГРАНИЦЫ
}

\author{
Александр Антонович Сциборовский (канд. психолог. наук, доцент) \\ Артем Владимирович Братко (канд. воен. наук)
}

Национальная академия Государственной пограничной службы Украины имени Богдана 


\title{
Хмельницкого, Хмельницкий, Украина
}

В данной статье авторами исследованы и научно обоснованы рекомендащии, определяющие единый подход департаментов Администрачии Государственной пограничной службы Украины, штабов региональных управлений, пограничных отрядов, командиров подразделений в организаџии применения подразделений из состава боевого резерва Главы Государственной пограничной службы Украины для усиления охраны государственной гранищы. Определены условия и правила привлечения подразделений из состава боевого резерва для усиления охраны государственной границы, порядок организаџии оперативно-служебной деятельности и порядок выполнения заданий.

Ключевые слова: боевые резервы, пограничные подразделения, государственная граница, мобильная группа, пограничный наряд, отдел пограничной службы.

\section{METHODICAL RECOMMENDATIONS ON ORGANIZING APPLICATIONS OF DEPARTMENTS FROM THE COMPOSITION OF MILITARY RESERVES FOR STRENGTHENING THE STATE BORDER PROTECTION}

\author{
Aleksandr A. Sciborovsky (Candidate of Psychology Sciences, Associate Professor, Head of the Department of Management \\ Personnel) \\ Artem V. Bratko (Candidate of Military Sciences, Associate Professor of a Department)

\section{National Academy of the State Border Service of Ukraine named after Bogdan Khmelnitsky, Khmelnitsky, Ukraine}

In this article, the authors have investigated and scientifically substantiated the recommendations that determine the unified approach of the Departments of the Administration of the State Border Service of Ukraine, the headquarters of regional administrations, border detachments, unit commanders in organizing the use of units from the reserve of the Head of the State Border Service of Ukraine to strengthen the state border guard. Terms and rules for attracting units from the combat reserve to enhance the protection of the state border, the order of organization of operational and official activities and the order of accomplishing tasks are determined.

Keywords: combat reserves, border units, state border, mobile group, frontier detachment, frontier service department.

\section{References}

1. On approval of the Instruction on the procedure of work of the bodies of the State Border Guard Service of Ukraine during the organization of operational and service activities [Pro zatverdzhennja Instrukciji pro porjadok roboty orghaniv upravlinnja Derzhavnoji prykordonnoji sluzhby Ukrajiny pid chas orghanizaciji operatyvnosluzhbovoji dijaljnosti], the order of the Administration of the State Border Guard Service of Ukraine from 08.10.2010 No. 755, NASBGSU, 2010, pp.10-15. 2. Temporary instruction on the use of mobile units, approved by the order of the Administration of the State Border Guard Service [Tymchasova instrukcija pro zastosuvannja mobiljnykh pidrozdiliv, zatverdzhena nakazom Administraciji Derzhprykordonsluzhby], the order of the Administration of the State Border Guard Service of Ukraine from 30.12.2005, No. 1039. 3. Instruction on the border guards service of the State Border Guard Service of Ukraine [Instrukcija pro sluzhbu prykordonnykh narjadiv Derzhavnoji prykordonnoji sluzhby Ukrajiny], approved by the order of the Ministry of Internal Affairs of Ukraine from 19.10.15, No. 1261. 4. On approval of the Instruction on organization of operational and service activities of the Border Guard Service of the State Border Guard Service of Ukraine [Pro zatverdzhennja Instrukciji z orghanizaciji operatyvno-sluzhbovoji dijaljnosti viddilu prykordonnoji sluzhby Derzhavnoji prykordonnoji sluzhby Ukrajiny], the order of the Administration of the State Border Guard Service of Ukraine from 29.12.2009 No. 1040 , Khmelnitsky NASBGSU, 2010, 175 p. 5. Authority of the management bodies for the organization of the application of units of the military reserve [Povnovazhennja orghaniv upravlinnja $\mathrm{z}$ orghanizaciji zastosuvanni pidrozdiliv skladu bojovogho rezervu], the order of the Administration of the State Border Guard Service of Ukraine from 22.12.2017, No. 120. 6. Kondrat V.F., Reshetnikov O.V. (2004), Problems of the effectiveness of the use of mobile units in the protection of the state border. [Problemy efektyvnosti vykorystannja mobiljnykh pidrozdiliv v okhoroni derzhavnogho kordonu] Naukovyj visnyk SBGSU, No. 4, pp. 14-16. 